\title{
Effect of Buckwheat Processing Products on Dough and Bread Quality Made from Whole-Wheat Flour
}

\author{
Vira Drobota ${ }^{\mathrm{a}}$, Anastasiya Semenova ${ }^{\mathrm{a}^{*}}$, Jelyzaveta Smirnova $^{\mathrm{a}}$, And Larisa \\ MYHONIK ${ }^{\mathrm{a}}$ \\ a National University of Food Technologies, 68 Volodymyrs'ka St., Kyiv, Ukraine \\ * Corresponding author \\ fantich@mail.ru \\ TEL: $+38-044-5136692$
}

Received: 18 December 2012; Published online: 18 April 2014

\begin{abstract}
The paper gives a brief overview of the current nutritional status of the Ukrainian population and describes useful buckwheat properties. The objective of the paper is to study the effect of buckwheat processing products (flour and flakes) on the technological process and quality of bread made from whole-wheat flour. This paper describes and analyzes research data on the rheological properties of dough samples which were determined by farinograph and amylograph.

Investigation of structural and mechanical properties of dough showed an increase in water-absorbing capacity in all samples when adding buckwheat products. Moreover, dough made with buckwheat flakes has a lower value of mixing tolerance index (by $47 \%$ ) than dough made from buckwheat flour, and a higher valorimetric value (by $20 \%$ ). Determination of dough properties by amylogram has shown that a sample containing buckwheat flakes has a higher maximum viscosity than a sample containing buckwheat flour. Determination of the gas-production and gas-retention capacity of dough is also presented, along with an analysis of the quality of finished products based on the results of laboratory baking tests.

The samples of bread supplemented with buckwheat flakes have better shape stability (by $21 \%$ ), specific volume (by $12 \%$ ) and porosity (by $11 \%$ ) than bread made from buckwheat flour. The organoleptic evaluation of finished product quality has shown that bread supplemented with buckwheat flakes has a more fluffy-texture, elastic crumb and uniform porosity than bread made from buckwheat flour. Buckwheat flakes proved to have a better effect on parameters of the technological process and quality of bread when compared with buckwheat flour.
\end{abstract}

Keywords: Whole-wheat; Buckwheat; Flakes; Flour

\section{Introduction}

The research of the National Academy of Medical Sciences of Ukraine has shown that foodstuffs which the Ukrainian population consume do not fully satisfy the physiological needs of the human body, therefore, contributing to high incidence of chronic disease and low life expectancy for Ukrainians. The medical and epidemiological data show a close link between nutritional status and the most common non-communicable diseases, especially the so-called diseases of the century: cardiovascular and oncological diseases, diabetes, obesity, osteoporosis and tooth decay. Irrational nutrition for most of the Ukraine's population causes the so-called hidden hunger as a result of a deficiency of micronutrients in the diet (Prodanchuk, Korec'kyj, \& N.M., 2005). 
Since bread is a staple food for the Ukrainian population, it is the most convenient product for correcting the nutritional and biological value of the diet. To raise the nutritional value of bread, there is a trend towards the use of unconventional grain raw materials and their processing products. The widespread use of such products relates to the presence in their composition of a whole complex of biologically active substances dietary fiber, vitamins, minerals, lipids and antioxidants. The high nutritional value and affordable price is the basis for their use in the development of new types of functional foods.

The role of cereals in the prevention and dietary correction of carbohydrate and lipid metabolism disorders is proven by epidemiological, clinical and experimental studies (Smith \& Tucker, 2011).

Among the products of processing groats for bread making, flour and flakes are mostly used (Mikhonik, 2008). There are reports of the addition of groat products, in the amount of $5-50 \%$ instead of flour mass, within the traditional recipes of bread (Czubaszek \& Karolini-Skaradzinska, 2005; Drobot, 1988; Drobot, Mikhonik, \& Grischenko, 2009, 2011; Gavrilova, 2008a; Gormley \& Morrissey, 1993; Kawka, Gorecka, \& Gasiorowski, 1999; Klava, Karklina, Rakcejeva, \& Zolnere, 2007; Romanov, Stabrovskaya, Ilyina, \& S.A., 2006; Smolina, 2009; Sobczyk, Haber, \& Witkowska, 2010; Vandakurova \& Stabrovskaya, 2008; Zaytseva \& Mogilny, 2010; Kazanskaya, Kuznetsova, \& Melnikova, 1998). On the other hand, the results of research concerning the use of buckwheat processing products, in combination with whole-wheat flour, are almost absent and in particular for the use of buckwheat flakes in baking.

Buckwheat is unique among cereal crops. It is used in the dietary nutrition of all age groups. It is known that the consumption of buckwheat groats helps to reduce the risk of atherosclerosis, hypertension and diabetes, reduce cholesterol level in blood and has a low glycemic index (Foster-Powell \& Miller, 1995; He et al., 1995; Drobot et al., 2009).

Buckwheat grain contains many valuable nutrients such as proteins, fats, polysaccharides, vitamins, minerals, fiber, and polyphenols (Kreft, Iked, Ikeda, \& Vombergar, 2010).
The protein content in buckwheat, according to different investigations, varies from $12 \%$ to 18.9\% (Christa, Soral-Smietana, \& Robaszewska, 2008). Its proteins are mostly digestible (up to $74 \%$ ), and are comprised mainly by $64.5 \%$ globulins and $12.5 \%$ albumins, and less significantly by $8 \%$ glutelins and $2.9 \%$ prolamins (Dvořáček, Čepková, \& Michalová, 2004; Nechayev, 2007). The essential amino acids of these proteins comprise a significant amount of arginine and lysine (Linwei, 2002). The limiting amino acids include methionine and threonine. The valine, leucine and phenylalanine contents of buckwheat protein are respectively similar to milk protein, beef protein and milk and beef proteins. The biological value of buckwheat protein is close to that of egg white and milk powder, and is considered as the most balanced and valuable (Parakhin, 2010).

Buckwheat contains $59 \%$ to $70 \%$ starch which is characterized by high resistance, i.e. it is not absorbed in the small intestine (Qian \& Kuhn, 1999). The dietary fiber within buckwheat comprises cellulose, hemicellulose, pectin and gum. Whole buckwheat grains contain $7 \%$ fiber, while the bran and seed coat contain $40 \%$ (Christa et al., 2008).

There are $1.5 \%$ to $4 \%$ lipids in buckwheat grain. The content of unsaturated fatty acids in the lipids is about $83.2 \%$, comprising oleic acid at $47.1 \%$ and linoleic acid at $36.1 \%$. There are also linolenic and other polyunsaturated fatty acids in the composition of lipids (Vang, Chen, \& Feng, 2010).

The content of minerals in whole buckwheat grain is $2-2.5 \%$ and in the kernel is $1.8-2.0 \%$ (Yildzogle-Ari, Altan, Altinkurt, \& Y., 1991). One hundred grams of buckwheat product (flour or flakes) can provide about $50 \%$ of the Recommended Daily Dose (RDD) of zinc, copper, manganese, magnesium, potassium, phosphorus and iron (Ikeda, Tomura, Yamashita, \& Kreft, 2001). The content of zinc in buckwheat is 2.6 times higher than that of other cereals. The contents of vitamin PP (nicotinic acid), B1 (thiamine), $\mathrm{B} 2$ (riboflavin) and $\mathrm{E}$ (tocopherol) in buckwheat exceeds all other cereals (Parakhin, 2010).

The main flavonoids in buckwheat grain are rutin and isovitexin. The total concentration of buckwheat flavonoids in the grain is $18.8 \mathrm{mg} / 100$ $\mathrm{g}$ of dry matter (Dietrych-Szostak \& Oleszek, 
Using Buckwheat Flakes and Flour in Bread Making |3

1999). Rutin (Quercetin-3-O-glucorhamnosid) possesses important therapeutic properties, including a positive impact on the elasticity of blood vessels, treatment of disorders of blood circulation and atherosclerosis, blood pressure reduction and stimulation of the body to use vitamin C (Yildzogle-Ari et al., 1991).

Several studies have reported the use of buckwheat products, such as flour, flakes, groats and extrudate, as substitutes for wheat flour in bakery, confectionery and pastry manufacturing technology (Borkowska \& Robaszewska, 2012; Gavrilova, 2008b; Vandakurova \& Stabrovskaya, 2008; Bonafaccia \& Kreft, 1994; Yıldız \& Bilgiçli, 2012; Baljeet, Ritika, \& Roshan, 2010; Wang \& Campbell, 2004; Lin, Liu, Yu, Lin, \& Mau, 2009).

The raw material for buckwheat flakes and buckwheat flour is buckwheat grain. The technology for making such buckwheat products provides hydrothermal treatments (HTT). HTT is interpreted as grain handling by water and heat for direct change (improvement) of the whole technological complex (flour milling, bakery and groat properties) (Kazakov \& Karpilenko, 2005). HTT, which is commonly used during the processing of oats, strongly affects the rheological properties of dough made from oats flour (Zhang, Moore, \& Doehlert, 1998). This operation leads to partial denaturing of protein, starch gelatinization and an increase in the amount of dextrin formation. In the production of flakes more stringent HTT processing procedures are used than for flour (Babich, Bayram-Gali, \& Kalinichenko, 2001).

Therefore, in this study we have compared the influence of buckwheat flakes and flour on the technological indices and quality of whole-wheat bread. The quantity of buckwheat products used in the mixtures was determined by previous studies, and constituted a $15 \%$ replacement of the whole-wheat flour mass (Semenova \& Mikhoník, 2012; Drobot, Mikhonik, \& Tesla, 2013).

\section{Materials and Methods}

Commercial whole-wheat flour (moisture content $13.2 \%$, protein $12.3 \%$, fat $2 \%$ and carbohydrates $60 \%$ ) which met the Ukraine State Standard (46.004.99) was used. Commercial buckwheat products were made from the same batch of buckwheat: buckwheat flakes (moisture content $8.4 \%$, protein $13.71 \%$, fat $2.41 \%$ and carbohydrates $67.2 \%$ ) and buckwheat flour (moisture content $9 \%$, protein $13.6 \%$, fat $2.35 \%$ and carbohydrates $66.5 \%$ ). The buckwheat HTT used in the study was carried out at a temperature of $90^{\circ} \mathrm{C}$, with a steam pressure of $0.25 \mathrm{MPa}$ and a duration of steaming of $5 \mathrm{~min}$. The mixture of whole-wheat flour with buckwheat flakes or buckwheat flour investigated was in the ratio of $85: 15$. The optimal ratio of buckwheat products and wheat flour in mixtures (85:15) was found in previous studies and based on the analysis of physical-chemical, biochemical and colloidal processes during dough formation and on the indicators of finished product quality according to a baking quality test (Semenova \& Mikhoník, 2012; Drobot et al., 2013). The sample from whole-wheat flour, without adding buckwheat, was taken as a reference sample. Agricultural cultures from the 2010-2011 harvest were used in the research.

Structural and mechanical properties of dough samples were determined by farinograph $(50 \mathrm{~g}$ of flour with humidity of $14 \%, 50 \mathrm{~g}$ reservoirs, CW Brabender Instruments. Inc., under constant mass of flour, by the AACC (2000) 54-21 method). Farinograms of dough samples were analyzed using the following parameters: water absorption (\%), dough development time (min), stability (min) and mixing tolerance index (BU). The amylase activity (gelatinized starch) was determined by amylograph (65 g of flour content with humidity of $14 \%$ and $450 \mathrm{ml}$ of distilled water, CW Brabender Instruments. Inc., by the AACC (2000) 22-10 method). Values of maximum suspension viscosity (BU) and gelatinization temperature $\left({ }^{\circ} \mathrm{C}\right)$ were determined by amylogram.

Gas-production of dough samples was determined by the volumetric method through the volume of carbon dioxide emission under conditions of constant temperature and pressure $(100$ 
$\mathrm{g}$ of mixture with humidity of $14 \%, 60 \mathrm{~cm}^{3}$ of water and $10 \mathrm{~g}$ of pressed yeast at fermentation temperature $+30{ }^{\circ} \mathrm{C}$ during $5 \mathrm{~h}$ ). According to this method, dough fermentation occurs in reservoirs tightly connected by a system of tubes and three-way stopcocks with glass measuring cylinders, which are slightly submerged into reservoirs with mineral oil. At the beginning of the process oil is sucked into a measuring cylinder up to a zero level. Using a system of clamps, access of 2 is provided to the measuring cylinder. During fermentation, $\mathrm{CO}_{2}$ gradually pushes oil from the cylinder. The oil volume pushed corresponds to the amount of $\mathrm{CO}_{2}\left(\mathrm{~cm}^{3}\right)$ emitted during fermentation (Drobot, 2006).

The gas-retention capacity was determined by observing the change in volume of dough samples in the cylinders, at a temperature of $+30{ }^{\circ} \mathrm{C}$ and relative humidity of $75 \%$ in the thermostat, from the beginning of fermentation up to the abscission time of dough.

The laboratory baking of the finished product samples was carried out according to the Ukraine State Standard (27669-88). The bread was baked from mixtures by the straight dough method. The dough was kneaded according to the recipe: wheat flour (reference sample) or a mixture (1000 g), compressed yeast (35 g), salt (22 g) and water (according to the results of farinograph). Mixing was carried out with a dough kneader. The fermentation time was $210 \mathrm{~min}$ at the temperature of $28^{\circ} \mathrm{C}$ and relative humidity of $80 \%$ in the thermostat. The dough punching down was carried out 120 min after mixing. After fermentation, divided and formed dough pieces were subjected to maturation and baking. Bread baking took place in an oven at a temperature of $200-210{ }^{\circ} \mathrm{C}$ for 30-35 min.

The bread indicators were defined 24 hours after baking. Bread volume was determined through laboratory volumeter. The instrument's operation is based on the measurement of millet grains equal to the volume of the tested bread. The shape stability index of bread was determined by the ratio of the height of the product to its diameter.

Physical and chemical parameters of quality of finished products (humidity, acidity, porosity) were determined by the Ukraine State Standard (7045:2009). Twelve panelists (students of
NUFT) were selected and trained according to ISO 11035:1994. Sensory evaluation was carried out by the nine score hedonic scale method (Peryam, 1998). These scores are given word descriptors from "liked extremely" (9 score) to "dislike extremely" (1 score). Panelists evaluated the appearance of bread (proper shape), color and state of the surface crust, color and texture of the crumb (chewing, elasticity, compactness and softness), aroma and taste.

All data are the average value of at least three independent determinations. The probability of results is obtained by statistical methods. Statistical analysis of results, including charts and diagrams, were performed using MS Office Excel software.

\section{Results and Discussion}

Effects of buckwheat flakes and flour on the structural and mechanical properties of dough are presented in Table 3. On adding buckwheat products to dough, its water-absorbing ability increases.

Buckwheat protein, containing $80 \%$ albumin and globulin, has a higher water-retaining capacity than wheat gluten (Vang et al., 2010). According to Juan, Yan, and Zhengbiao (2009), buckwheat starch granules are mainly polygonal and less spherical, and have surfaces which are rough. This results in high stabilizing and thickening properties, and the characterization of buckwheat starch as a substance to enhance stickiness. Among non-starch buckwheat polysaccharides, pentosans play the most important role by imparting the ability to absorb and retain water. The amount of pentosans in buckwheat is higher than that of wheat. Buckwheat, as a pentosancontaining raw material, is used to simulate the baking properties of rye flour, in which waterbinding and water-absorbing capacity is mainly determined by non-starch polysaccharides (Xu, Zhang, Wang, \& Wang, 2008; Drobot et al., 2009; Barsukova, Reshetnikov, \& Krasil'nikov, 2011). Thus, the increase of dough water-absorbing ability with raw buckwheat can be explained by peculiar structure of buckwheat starch grains, protein composition and high content of non-starch polysaccharides.

\begin{tabular}{l|l|l|l} 
IJFS & April 2014 & Volume 3 & pages 1-12
\end{tabular} 
Using Buckwheat Flakes and Flour in Bread Making $\mid 5$

Table 1: Structural and mechanical properties of dough, with and without buckwheat products, by farinograph and amylograph indicators $(\mathrm{n}=3, \mathrm{p} \geq 0.95)$

\begin{tabular}{lccc}
\hline Parameters & $\begin{array}{c}\text { Reference } \\
\text { sample }\end{array}$ & $\begin{array}{c}\text { Mixture with } \\
\text { buckwheat flour }\end{array}$ & $\begin{array}{c}\text { Mixture with } \\
\text { buckwheat flakes }\end{array}$ \\
\hline Dough development time, min. & $8.0 \pm 0.21^{a}$ & $8.0 \pm 0.28^{a}$ & $11.0 \pm 0.29^{b}$ \\
Dough stability, min. & $1.0 \pm 0.01^{a}$ & $1.0 \pm 0.01^{a}$ & $1.0 \pm 0.01^{a}$ \\
Mixing tolerance index, BU & $90.0 \pm 3.66^{a}$ & $230 \pm 3.49^{b}$ & $110 \pm 3.81^{c}$ \\
Absorption, \% & $65.0 \pm 1.23^{a}$ & $73.6 \pm 1.19^{b}$ & $71.2 \pm 1.11^{b}$ \\
Valorimetric value, BU & $71.0 \pm 1.33^{a}$ & $64 \pm 1.31^{b}$ & $80 \pm 1.33^{c}$ \\
Maximum suspension viscosity, BU & $320 \pm 1.68^{a}$ & $315 \pm 1.81^{b}$ & $335 \pm 2.22^{c}$ \\
Gelatinization temperature, ${ }^{o} \mathrm{C}$ & $52.0 \pm 0.03^{a}$ & $50.5 \pm 0.12^{b}$ & $48.3 \pm 0.57^{c}$ \\
\hline
\end{tabular}

The values are the mean \pm S.D of three independent determinations. Different letters in the same row indicate that means were significantly different $(n=3, p \geq 0.95)$.

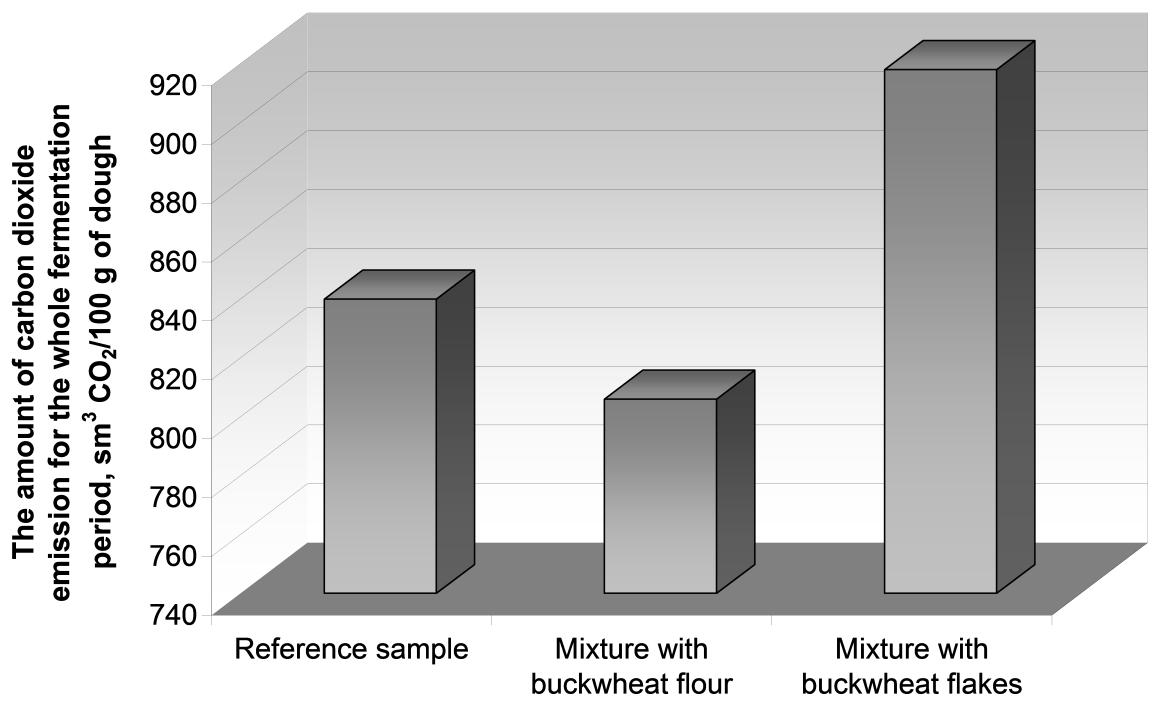

Figure 1: Total gas-production of dough samples without buckwheat, and with buckwheat flour and flakes 
$6 \mid$ Drobot et al.

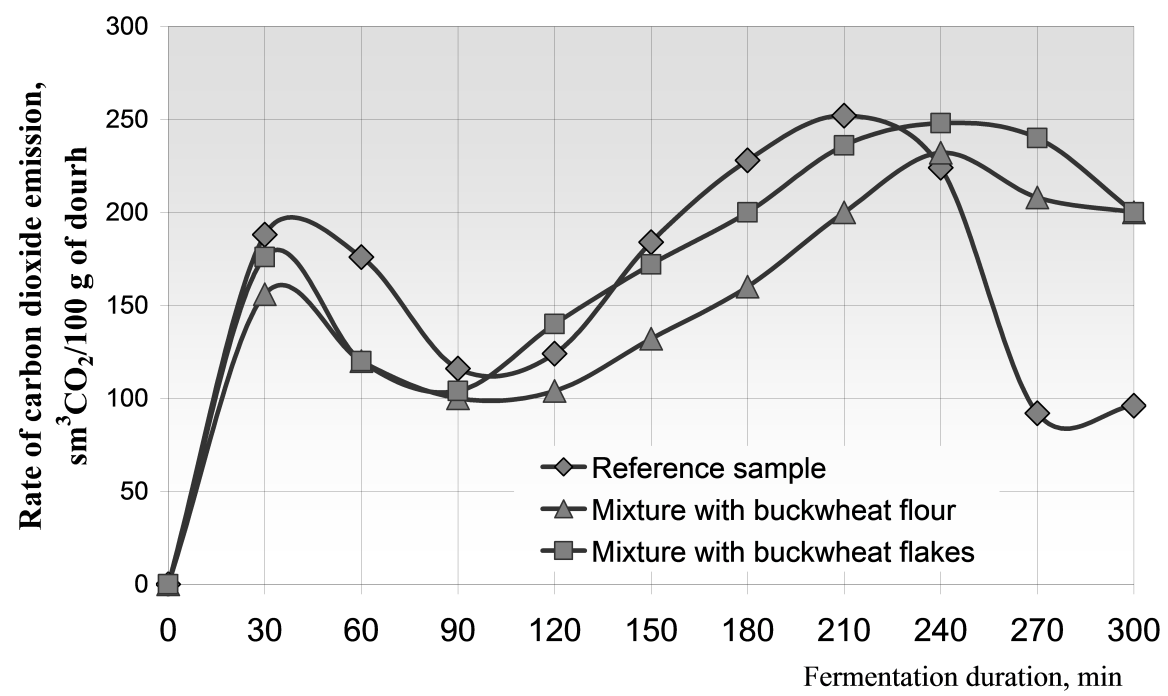

Figure 2: Dynamics of gas-production in dough without buckwheat, and with buckwheat flour and flakes

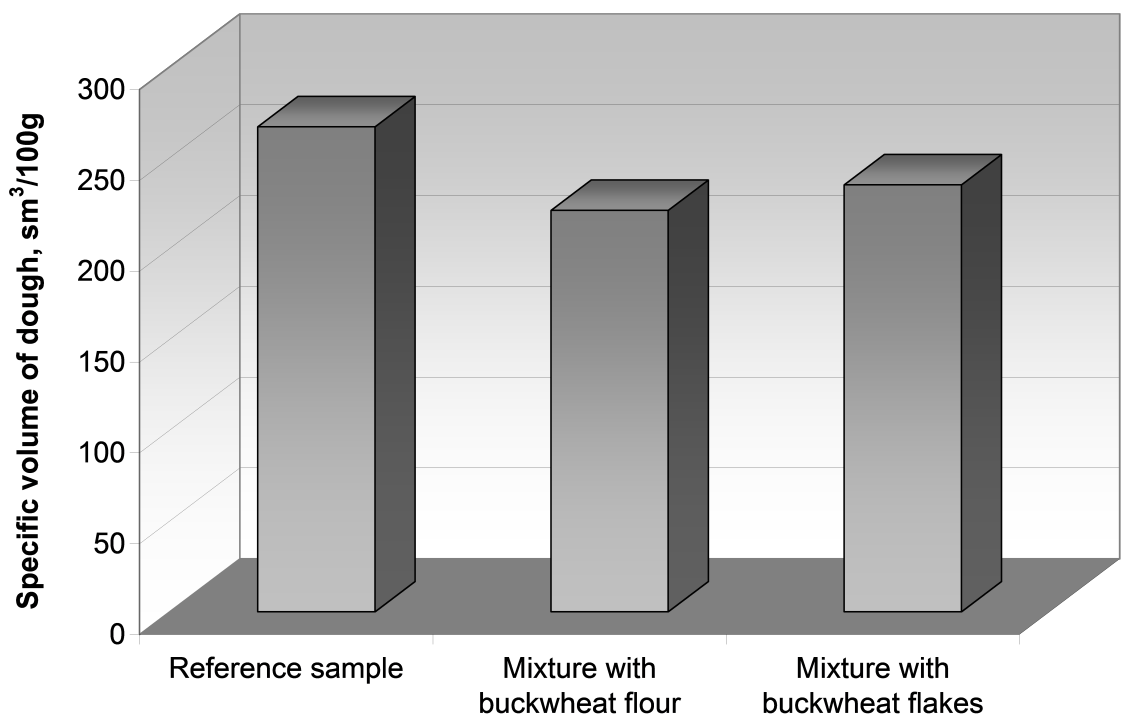

Figure 3: Gas-retention ability of dough samples without buckwheat, and with buckwheat flour and flakes 
Using Buckwheat Flakes and Flour in Bread Making $\mid 7$

Table 2: Process and quality indicators of whole-wheat bread, with and without buckwheat processing products

\begin{tabular}{|c|c|c|c|}
\hline Parameters & $\begin{array}{l}\text { Reference } \\
\text { sample }\end{array}$ & $\begin{array}{c}\text { Mixture with } \\
\text { buckwheat flour }\end{array}$ & $\begin{array}{c}\text { Mixture with } \\
\text { buckwheat flakes }\end{array}$ \\
\hline \multicolumn{4}{|c|}{ Physical and chemical parameters } \\
\hline \multicolumn{4}{|l|}{ Dough } \\
\hline \multicolumn{4}{|l|}{ Acidity, acidity degrees } \\
\hline initial & $4.2 \pm 0.02^{a}$ & $4.6 \pm 0.05^{b}$ & $4.4 \pm 0.11^{c}$ \\
\hline final & $5.0 \pm 0.03^{a}$ & $5.2 \pm 0.02^{b}$ & $5.2 \pm 0.04^{b}$ \\
\hline Moisture content, $\%$ & $45.0 \pm 0.25^{a}$ & $47.5 \pm 0.25^{b}$ & $46.5 \pm 0.34^{c}$ \\
\hline \multicolumn{4}{|l|}{ Bread } \\
\hline Specific loaf volume, $\mathrm{sm}^{3} / \mathrm{g}$ & $2.77 \pm 0.08^{a}$ & $1.89 \pm 0.06^{b}$ & $2.15 \pm 0.14^{c}$ \\
\hline Porosity, \% & $76 \pm 0.72^{a}$ & $64 \pm 1.23^{b}$ & $72 \pm 1.53^{a}$ \\
\hline Shape stability index (h/d) & $0.31 \pm 0.01^{a}$ & $0.30 \pm 0.11^{a}$ & $0.38 \pm 0.01^{b}$ \\
\hline Acidity, acidity degrees & $2.8 \pm 0.01^{a}$ & $2.9 \pm 0.01^{b}$ & $2.9 \pm 0.01^{b}$ \\
\hline Moisture content, \% & $44.0 \pm 0.12^{a}$ & $46.5 \pm 0.71^{b}$ & $45.5 \pm 1.11^{c}$ \\
\hline \multicolumn{4}{|c|}{ Organoleptic indicators } \\
\hline \multicolumn{4}{|l|}{ Bread appearance: } \\
\hline Bread crust & convex, glossy & convex, glossy & $\begin{array}{c}\text { convex, glossy with } \\
\text { inclusion of } \\
\text { buckwheat flakes }\end{array}$ \\
\hline Crumb & springy & $\begin{array}{l}\text { less springy, } \\
\text { slightly sticky }\end{array}$ & springy \\
\hline Internal texture & $\begin{array}{l}\text { with small pores, uniform } \\
\text { with thin-walled cells }\end{array}$ & $\begin{array}{l}\text { non-uniform } \\
\text { with thick-walled cells }\end{array}$ & $\begin{array}{c}\text { with small pores, } \\
\text { with thick-walled cells }\end{array}$ \\
\hline Taste and flavour & typical of wheat bread & $\begin{array}{l}\text { with flavour } \\
\text { and taste } \\
\text { of buckwheat }\end{array}$ & $\begin{array}{c}\text { pleasant taste } \\
\text { with flavour and a } \\
\text { smack of buckwheat }\end{array}$ \\
\hline
\end{tabular}

The values are the mean \pm S.D of three independent determinations. Different letters in the same row indicate that means were significantly different $(n=3, p \geq 0.95)$. 
8| Drobot et al.

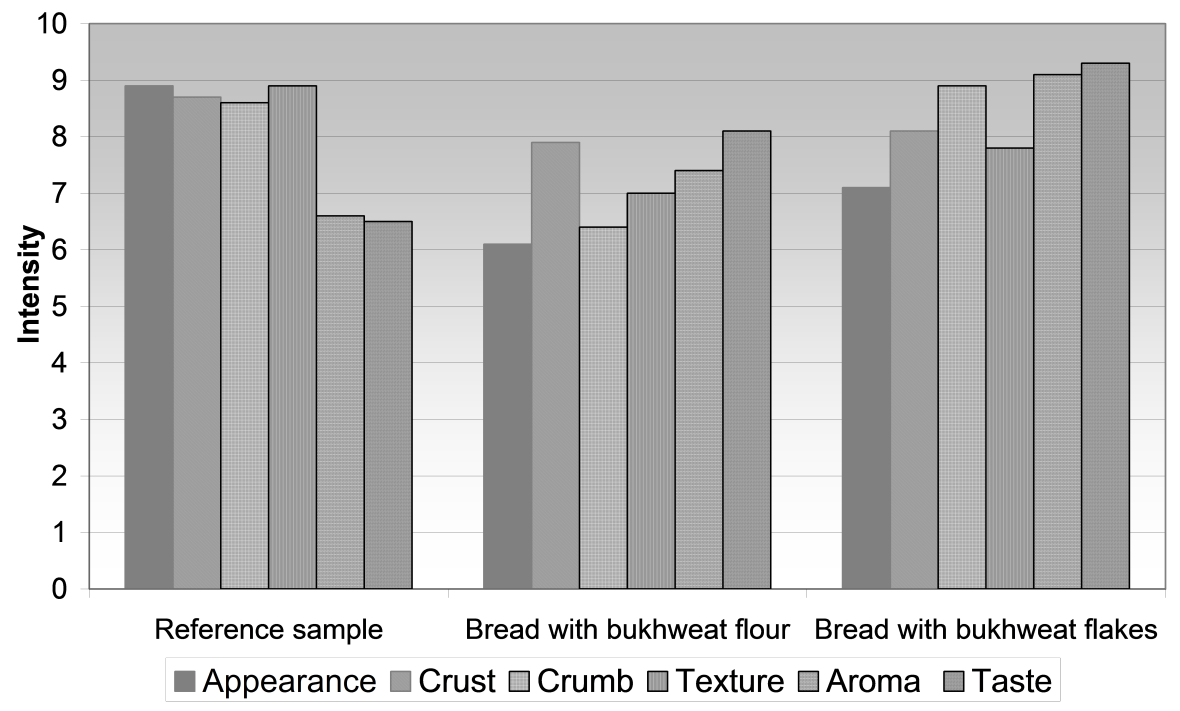

Figure 4: Sensory evaluation of bread without buckwheat, and with buckwheat flour and flaked

Adding buckwheat flour and flakes also affected the mixing tolerance index of dough, and to a greater extent when adding buckwheat flour rather than flakes. Finer buckwheat flour grinding, compared with flakes, helps to increase the amount of water-soluble substances in the medium. Increasing the mixing tolerance index of dough with buckwheat is also the result of protein and pentosans high hydration, on the one hand, and on the other hand disaggregation of polymers under the influence of hydrolytic enzymes (Drobot, 2005). Accordingly, we can observe that dough from buckwheat flour has absorbed more water and thus, has had a greater mixing tolerance index.

The valorimetric value was highest in the dough sample with buckwheat flakes, which indicates an improved mixing ability of dough with flakes. Formation of a bread crumb is largely dependent on the ability of starch granules to swell and gelatinize during baking. The influence of raw buckwheat addition on the starch gelatinizing process was evaluated by amylograph at the point of maximum viscosity observed for the suspensions. This parameter reflects the process of starch gelatinizing from the beginning of intensive swelling of its grains (increasing the viscosity of the suspension) to their gradual destruction (decreasing the viscosity of the suspension).

The gelatinization of the starch suspension with buckwheat flakes took place at a lower temperature. This suspension had a higher viscosity than that of the reference sample because flakes have a greater dispersibility and a lower specific surface than flour. Therefore, cereal starch is less affected by amylolysis and the gelatinized suspension is not diluted. This should have a positive effect on the state and structure of a crumb. Gas-production capacity characterizes the ability of the flour mixture to provide the dough fermentation process with sugar, maturation of dough pieces and coloring of a bread crust. It depends on the content of its sugars in mixtures and its saccharifying ability (Drobot, 2005). Buckwheat differs from wheat flour in its starch, monosaccharide and disaccharide contents (Wei, Zhang, \& Li, 1995; Grischenko, 2011). Therefore, the replacement of a proportion of wheat flour can affect the fermentation process. The highest index of overall gas-production (Fig. 1) belonged to the dough sample with flakes, which can be explained by the technology of their production. HTT of flakes promotes the intensification of enzymatic hydrolysis of their polymers and increases the 
Using Buckwheat Flakes and Flour in Bread Making $\mid 9$

amount of nutrients for the yeast. Lower gas formation in the dough with buckwheat flour is explained by a lower content of its own sugars and lower saccharifying ability than in wheat flour.

To predict the influence of raw buckwheat on dough maturation time, the dynamics of gas formation in the dough, with this raw material, was determined (Fig. 2). The second extremum, indicating the yeast transferring to maltose fermentation in samples with buckwheat raw material, occurred 30 minutes later than the reference sample. This proves the necessity to increase the time of fermentation for buckwheat flour and flakes.

During dough fermentation, a crumbly structure formation of bread occurs due to the accumulation of $\mathrm{CO}_{2}$. So the ability of the gluten network to hold carbon dioxide, which is produced during fermentation, is of fundamental importance. Gas-retention capacity provides the resilientelastic properties of dough. Gas-retention capacity reflects the time when the dough starts to fall off and lose its shape. Adding buckwheat processing products impaired the ability of dough to retain carbon dioxide by $8-15 \%$ (Fig. 3). This is explained by the fact that buckwheat does not contain glutenous proteins capable of forming a linked structure (network), namely gliadin and glutelin fractions (Nechayev, 2007).

Reduction in gas production and bread $\mathrm{CO}_{2}-$ retaining ability leads to a decrease in specific volume and porosity, as confirmed by a baking quality test. The use of raw buckwheat led to a decrease in specific volume and porosity of the finished products (Tab. 3) and a shape stability index (the ratio of bread height to its diameter) improvement. Adding buckwheat raw materials promotes an increase of the initial and final acidity due to the presence of greater amounts of organic acids in buckwheat compared to wheat flour. Bread containing buckwheat flakes had better consumer properties compared to bread containing buckwheat flour. It had a larger volume, mellowed crumbs, well-colored crust and a more delicate taste and flavor.

Participants of sensory (Fig. 4) analysis liked to some extent bread appearance with buckwheat raw materials. Bread with buckwheat flakes was scored best for taste qualities. Unlike the bread with buckwheat flour, it had a pleasant taste, with flavor, and a smack of buckwheat. Participants approved texture and color of the crumb in the control sample and bread with buckwheat flakes.

\section{Conclusions}

There are a number of advantages of raw buckwheat chemical composition in comparison with wheat flour, which confirms the feasibility of its use as an additional raw material in the manufacturing of bakery products for functional and prophylactic purposes (Bojňanská, Frančáková, Chlebo, \& Vollmannová, 2009, 2010; Zhou, Li, Zhao, \& G., 2006; Christa et al., 2008).

The research conducted has shown that adding buckwheat processing products leads to a slight decrease of technological indices and consumer characteristics of finished bread products. Among the studied samples, with added raw buckwheat, the bread containing buckwheat flakes had the best consumer properties. Given the content of useful components in buckwheat processing products, it is appropriate to use friable mixtures from whole-wheat flour and buckwheat flakes for bread making.

\section{References}

AACC. (2000). American association of cereal chemists. Methods 54-21, 22-10. Approved Methods of the AACC. $10^{t h}$ ed. St. Paul: The Association.

Babich, M., Bayram-Gali, V., \& Kalinichenko, V. (2001). Grain processing to ready-to-eat cereal flakes and grains. Khraneniye $i$ pererabotka zerna (in Russian), 9, 38-40.

Baljeet, S., Ritika, B., \& Roshan, L. (2010). Studies on functional properties and incorporation of buckwheat flour for biscuit making. International Food Research Journal, 17(4), 1067-1076. Retrieved from http:// www.ifrj.upm.edu.my/

Barsukova, N., Reshetnikov, D., \& Krasil'nikov, V. (2011). Food engineering: technology gluten-free flour products. Khraneniye $i$ pererabotka zerna), 4, 43-46. 
Bojňanská, T., Frančáková, H., Chlebo, P., \& Gažar, R. (2010). Possibility of exploitation of buckwheat in bread-making and advantages of enriched bread consumption. Potravinarstvo (in Slovak), 4(1), 8-12. Retrieved from http://www.potravinarstvo. com

Bojňanská, T., Frančáková, H., Chlebo, P., \& Vollmannová, A. (2009). Rutin content in buckwheat enriched bread and influence of its consumption on plasma total antioxidant status. Czech J. Food Sci. 27, 236-240. Retrieved from http : / / www . agriculturejournals.cz

Bonafaccia, G. \& Kreft, I. (1994). Technological and qualitative characteristics of food products made with buckwheat. Fagopyrum, 14, 35-42. Retrieved from http:// lnmcp.mf.uni-lj.si

Borkowska, B. \& Robaszewska, A. (2012). Use of buckwheat grain in various industry branches. Zeszyty Naukowe Akademii Morskiej w Gdyni (in Poland), 73, 43-55. Retrieved from http://zeszyty.am.gdynia. $\mathrm{pl}$

Christa, K., Soral-Smietana, M., \& Robaszewska, A. (2008). Buckwheat grains and products - nutritional and prophylactic value of their components - a review. Czech J. Food Sci. 26(3), 153-162. Retrieved from http:// www.agriculturejournals.cz

Czubaszek, A. \& Karolini-Skaradzinska, Z. (2005). Effects of wheat flour supplementation with oat products on dough and bread quality. Pol. J. Food Nutr. Sci. $14(3), 281-$ 286. Retrieved from http://journal.pan. olsztyn.pl

Dietrych-Szostak, D. \& Oleszek, W. (1999, October). Effect of processing on the flavonoid content in buckwheat (fagopyrum esculentum moench) grain. Journal of Agricultural and Food Chemistry, 47(10), 4384-4387. doi:10.1021/jf990121m

Drobot, V. (1988). Using of unconventional materials in the baking industry. (p. 152). Kiev, Urozhay Publ. (in Russian).

Drobot, V. (2005). Bakery production technology. Kyiv: Lotos Publ.(in Ukranian).

Drobot, V. (2006). Laboratory workshop on the technology of baking and pasta pro- duction: studies. Handbook. Kyiv: Tsentr navchal'noï literatury Publ. (in Ukrainian). Drobot, V., Mikhonik, L. A., \& Grischenko, A. (2011). Using buckwheat flour in the manufacture of gluten-free bread. Khraneniye i pererabotka zerna (in Russian), 4, 61-62. Retrieved from http://dspace.nuft.edu.ua/ jspui/

Drobot, V., Mikhonik, L., \& Tesla, A., O. Semenova. (2013). The use of cereal flakes in the technology of wellness products. Khlibopekars'ka $i$ kondyters'ka promyslovist' Ukrainy (in Ukrainian), 1(98), 3-4. Retrieved from http://dspace.nuft.edu . ua/jspui/

Drobot, V., Mikhonik, L., \& Grischenko, A. (2009). Products of functional purposes: prospects for using of products of processing cereals in breadmaking. Mir produktov (in Russian), 9, 6-8. Retrieved from http: //dspace.nuft.edu.ua/jspui/

Dvořáček, V., Čepková, P., \& Michalová, A. (2004). Protein Content Evaluation of Several Buckwheat Varieties. In Proceedings of the $9^{\text {th }}$ International Symposium on Buckwheat. Paper presented at $9^{\text {th }}$ International Symposium on Buckwheat, held at Prague, 18-22 August, 2004 (734-736). Prague: Research Institute of Crop Production. Retrieved from http://nmcp.mf.uni-lj.si

Foster-Powell, K. \& Miller, J. (1995). International tables of glycemic index. The American Journal of Clinical Nutrition, 62(4), 871-890. Retrieved from http : / / ajcn . nutrition.org

Gavrilova, O. M. (2008a). Application of buckwheat flour in the production of white bread. Khleboprodukty (in Russian), 7, 3637 .

Gavrilova, O. M. (2008b). Technology development of bread with buckwheat flour application. Synopsis Ph.D. sci. diss. Moscow State University of Food Production, Moscow, 25 p (in Russian). Retrieved from http://mgupp.ru

Gormley, T. R. \& Morrissey, A. (1993). A note on the evaluation of wheaten breads containing oat flour or oat flakes. Irish Journal of Agricultural and Food Research, 32(2), 205-209. 
Grischenko, A. (2011). The refinement of glutenfree bread technologies (Doctoral dissertation, National University of Food Technologies, Kyiv). 222 p. (in Ukrainian). Retrieved from http:// dspace.nuft.edu.ua/ jspui/

He, J., Klag, M.J., Whelton, P., Mo, J., Chen, J., .. e, G. (1995). Oats and buckwheat intakes and cardiovascular disease risk factors in an ethnic minority of china. Am. J. Clin. Nutr. 61(2), 366-372.

Ikeda, S., Tomura, K., Yamashita, Y., \& Kreft, I. (2001). Minerals in buckwheat flours subjected to enzymatic digestion. Fagopyrum, 18, 45-48. Retrieved from http://lnmcp. mf.uni-lj.si

Juan, G., Yan, H., \& Zhengbiao, G. (2009). Study on physico-chemicai properties of buckwheat starch. Food and Fermentation Industries, 30(11), 104-108.

Kawka, A., Gorecka, D., \& Gasiorowski, H. (1999). The effect of commercial barley flakes on dough characteristic and bread composition. EJPAU, 2(2), 1-8.

Kazakov, E. \& Karpilenko, G. (2005). Biochemistry of grains and their products. $3^{\text {th }} \mathrm{ed}$., St. Petersburg, GIORD Publ., 512 p. (in Russian).

Kazanskaya, L., Kuznetsova, L., \& Melnikova, G. (1998). New varieties of bread with food fibers. Khleboprodukty (in Russian), 2, 16.

Klava, D., Karklina, D., Rakcejeva, T., \& Zolnere, I. (2007). Application of oat products in wheat bread technology. Maisto chemija ir technologija, 41(2), 19-23. Retrieved from http://www.lmai.lt

Kreft, I., Iked, K., Ikeda, S., \& Vombergar, B. (2010). The development of novel functional food products based on common and tartary buckwheat. In V: Zotikov, V. I. (ur.), Parakhin N. V. (ur.).. Advances in Buckwheat Research - Proceedings of the $11^{\text {th }}$ International Symposium on Buckwheat. Paper presented at the $11^{\text {th }}$ International Symposium on Buckwheat, held at Orel, $19^{t h}-23^{r d}$ July, 210. Orel: AllRussia Research Institute of Legumes and Groat Crops, 37-40.

Lin, L., Liu, H., Yu, Y., Lin, S., \& Mau, J. (2009). Quality and antioxidant property of buck- wheat enhanced wheat bread. Food Chem. 112(4), 987-991.

Linwei, L. (2002). Buckwheat deep process in china. Journal of Northwest A\& F University, 30, 83-85.

Mikhonik, L. (2008). The refinement of bread technology from wheat flour of high output (Doctoral dissertation, National University of Food Technologies, Kyiv). $143 \mathrm{p}$ (in Ukrainian).

Nechayev, A. (Ed.). (2007). Food chemistry. 4th ed., revised and enlarged. St. Petersburg: GIORD (in Russian).

Parakhin, N. (2010). Buckwheat: biological features and ways to implement them. Vestnik OrelGAU: Aktualnye voprosy vyrashchivaniya $i$ pererabotki grachikhi (in Russian), 4(10), 4-8.

Peryam, D. (1998). (Chambers E. Intro) The 9-Point Hedonic Scale: Dr. David R. Peryam's Early Papers on the Most Widely Used Sensory Scale in the World. Chicago: Peryam \& Kroll Research Corporation. Retrieved from http://www.pk-research.com

Prodanchuk, M., Korec'kyj, V., \& N.M., O. (2005). To the problem of food safety the population of ukraine. Problemy harchuvannja, no.2. pp. 5-9. (In Ukrainian).

Qian, J. \& Kuhn, M. (1999). Physical properties of buckwheat starches from various origins. Stärke, 51 (2-3), 81-85.

Romanov, A., Stabrovskaya, O., Ilyina, A., \& S.A., S. (2006). Using of cereal flakes in the manufacture of bakery products. Khraneniye $i$ pererabotka selkhozsyrya (in Russian), 2, 54-55.

Semenova, A. \& Mikhoník, L. (2012). Recipe composition with buckwheat flakes for home baking. The program and materials $78^{\text {th }}$ International Conference of young scientists, post-graduate students and students «Scientific achievement of young people - solving problems of humankind in the twentieth century», Kiev, NUHT Publ., 1, 75 - 76 (in Ukrainian). Retrieved from http : / / dspace.nuft. edu . ua/jspui / handle/123456789/4400

Smith, C. \& Tucker, K. (2011). Health benefits of cereal fiber: a review of clinical trials. Nutrition Research Reviews, 24, 118-131. 
Smolina, Y. (2009). Oats - it's delicious and useful. Khleboprodukty (in Russian), 9, 50-51.

Sobczyk, M., Haber, T., \& Witkowska, K. (2010). Effect of the addition of oatmeal to the quality of wheat dough and bread. Acta Agrophysica (in Polish), 16(2), 423-433.

Ukraine State Standard. (27669-88). Wheat bread flour. Method for experimental laboratory bread making. Moscow, Standartinform Publ., 14 p. (in Russian).

Ukraine State Standard. (46.004.99). Wheat flour. Technical Conditions. Kyiv, Derzhspozhyvstandard of Ukraine Publ. (in Ukrainian).

Ukraine State Standard. (7045:2009). Bakery products. Methods for determination of physical and chemical parameters. Kyiv, Derzhspozhyvstandard of Ukraine Publ. (In Ukrainian).

Vandakurova, N. \& Stabrovskaya, O. (2008). Using of buckwheat processing products in the manufacture of flour products (use of buckwheat flour in the production of pasta and buckwheat flake - in breadmaking). Tekhnika $i$ tekhnologiya pishchevykh proizvodstv (in Russian), 1, 76-80. Retrieved from http://www.kemtipp.ru

Vang, I., Chen, D., \& Feng, I. (2010). The state of process production and development of strategies with regard to the products of buckwheat in china. Vestnik OrelGAU: Aktualnye voprosy vyrashchivaniya $i$ pererabotki grachikhi (in Russian), 4(10), 9-14.

Wang, Y. \& Campbell, C. (2004). Buckwheat production, utilization, and research in china. Fagopyrum, 21, 123-133. Retrieved from http://lnmcp.mf.uni-lj.si

Wei, Y.-M., Zhang, G.-Q., \& Li, Z.-X. (1995). Study on nutritive and physico-chemical properties of buckwheat flour. Nahrung, 39, 48-54. Retrieved from http://lnmcp.mf. uni-lj.si

Xu, Z., Zhang, Z., Wang, A., \& Wang, T. (2008). Assay of pentosan content in tartary buckwheat from southwest china. Seed, 27(5), 23-25.

Yildzogle-Ari, N., Altan, V., Altinkurt, O., \& Y., O. (1991). Pharmacological effects of rutin. Phytotherapy Res. 5, 19-23.
Yıldız, G. \& Bilgiçli, N. (2012). Effects of whole buckwheat flour on physical, chemical, and sensory properties of flat bread, lavaş. Czech J. Food.Sci. 30, 534-540. Retrieved from http://www.agriculturejournals.cz

Zaytseva, T. \& Mogilny, M. (2010). Using of cereals and legumes flakes in baking. Izvestiya VUZov. Pishchevaya tekhnologiya (in Russian), 1, 33-35.

Zhang, D., Moore, W., \& Doehlert, D. (1998, September). Effects of oat grain hydrothermal treatments on wheat-oat flour dough properties and breadbaking quality. Cereal Chemistry, 75(5), 602-605. doi:10.1094/ CCHEM.1998.75.5.602

Zhou, S., Li, L., Zhao, Y., \& G., C. (2006). Production of the buckwheat bread and study on the function of its blood sugar reduction. Grain Processing, 5. Retrieved from http : / / en . cnki.com . cn / Journal_en / B B024-XBLY-2006-05.htm 